Apidologie, 1988, 19 (2), 209-218

\title{
LABORATORY FEEDING OF VARROA JACOBSONI OUDEMANS ON NATURAL AND ARTIFICIAL DIETS (ACARI : VARROIDAE)
}

\author{
W.A. BRUCE ${ }^{1 *}$, F. CHIESA ${ }^{2}$, S. MARCHETTI ${ }^{2}$ and D.A. GRIFFITHS ${ }^{3}$ \\ 1. Stored-Product Insects Research and Development Laboratory, \\ U.S. Department of Agriculture, Agricultural Research Service, Savannah, GA 31403 \\ 2. Istituto di Difesa delle Piante, Universita degli Studi di Udine, Udine, Italia \\ 3. Storage Pests Department, Ministry of Agriculture, Fisheries, and Food, \\ Slough Laboratory, Berks, England
}

\begin{abstract}
SUMMARY
Varroa jacobsoni, a mite parasite of honey bees, pierced a synthetic membrane of stretched Parafilm ${ }^{(13}$ (approximately $10 \mu \mathrm{m}$ thickness) and fed on a modified artificial diet developed for the storedproduct mite, Pyemotes tritici. Under laboratory conditions $\left(35 \pm 1{ }^{\circ} \mathrm{C}\right.$ and $\left.85 \% \mathrm{RH}\right)$ all fecding stages of $V$. jacobsoni fed on the artificial diet and diet was incorporated into eggs. Females oviposited successfully in the environment of an artificial cell. Eggs hatched but protonymphs failed to molt to the dcutonymphal stage, thus a complete life cycle was not obtained.
\end{abstract}

\section{INTRODUCTION}

Varroa jacobsoni Oudemans is a mite ectoparasite of honey bees that is found throughout Europe and Asia. Its potentially devastating impact on apiculture should neither be ignored nor underestimated in those countries where infestations already occur (DE JoNg et al., 1982). Countries such as the United States, Canada, Australia, and New Zealand fortunate enough to be free from infestation must not become complacent but must participate actively in cooperative efforts for the study, containment, and elimination of this serious threat to world agriculture. In this regard, the European Economic Community (EEC) countries have taken the lead in a coordinated research effort to study both the basic and applied aspects of this problem (Cavalloro, 1983 ; Griffiths et al., 1983).

Because of the unique biology of this parasite, adequate study of its behavior has been greatly impaired. It is extremely difficult to study feeding, mating, and ovipositing behavior when the organism is sealed in an opaque cell sequestered within a bee hive. Therefore, researchers worldwide would (USA).

* Present address : USDA-ARS, Beneficial Insects Laboratory, BARC-East, Beltsville MD 20705 
benefit if large numbers of standardized, laboratory-reared mites of all stages could be produced. The possibility of rearing $V$. jacobsoni in the laboratory on an artificial diet was suggested to the senior author by Dr. Donald Griffiths following the Third International Working Conference on Stored-Product Protection, Manhattan, Kansas, USA, 1983. The presentation that the senior author had given at this meeting concerned the laboratory rearing of Pyemotes tritici (Lagrèze-Fossat and Montané), a mite ectoparasite of stored-product insects. Both $P$. tritici and $V$. jacobsoni pierce the integument of their host insect and feed on its hemolymph. The possibility that $V$. jacobsoni would also feed through the same synthetic membrane and on the same artificial medium as that developed for $P$. tritici seemed probable and worthy of study. The discussions that followed resulted in a proposal being submitted to and accepted by the EEC, Experts' Group on Varroatosis. The overall objective was clear: develop an artificial rearing technique for $V$. jacobsoni. Specific objectives of this study were to determine if : (1) female $V$. jacobsoni would probe, pierce and feed through a synthetic membrane; (2) other life stages would also feed through the membrane ; (3) $V$. jacobsoni would feed on a non-insect, artificial diet and lay eggs ; (4) $V$. jacobsoni could complete its life cycle when fed an artificial diet and reared under laboratory conditions.

This paper reports the results of research conducted at the Institute for Plant Protection, University of Udine, Udine, Italy during a 4 month period (May 1 - August 31, 1986).

\section{MATERIALS AND METHODS}

All life stages of $V$. jacobsoni were obtained from colonics of honcy bees derived from frec-flying crosses and re-crosses between Apis mellifera carnica and Apis mellifera ligustica, maintained by the Institute for Plant Protection, University of Udine. All worker and drone brood as well as comb and wax necessary for this study were collected from these hives. Ouality and age of brood used in all tests were determined by a qualified beckeeper. All laboratory reared mites were kept in a chamber maintained at $35 \pm 1{ }^{\circ} \mathrm{C}$ and $85 \pm 2 \% \mathrm{RH}$.

\section{Membranes}

Various membranes were brought from the United States to be tested : all were readily available and inexpensive. Membranes tested were: Handi-wrap. Handi-wrap II, Glad wrap ${ }^{\mathrm{TM}}$, Saran wrap, nitex cloth, silk, and Parafilm ${ }^{(4)}$. The first four were made into liquid-filled sachets or sacs using heat-sealing techniques, the nitex $(25 \mu \mathrm{m})$ and silk were tightly woven and would hold liquids, and the Parafilm could be stretched, molded, filled with liquid, and pressure sealed. Theses diet-filled sacs were then incorporated into various chambers for fecding studies.

Test Chambers

All test or rearing chambers used for mites were modified from readily available laboratory items and included glass tubing. ELISA blocks, and honey bee queen rearing cells. A small hole was drilled

(4) Mention of a proprictary product does not constitute an endorsement of this product by the USDA. 
into the bottom of each cell of a micro ELISA block to allow easy placement of mites and was stoppered with sponge to allow air exchange. The top opening of the cell was fitted with a synthetic membrane through which feeding could take place. Oueen cells were modified in the following way: the hole in the bottom of the tapered cup was covered with $20 \mu \mathrm{m}$ nylon mesh and placed in the holding stand ; another cup, fitted into the first, provided a suitable opening in which to place dict-filled containers. The opening in the bottom of the holding stand provided for ventilation (Fig. 1).

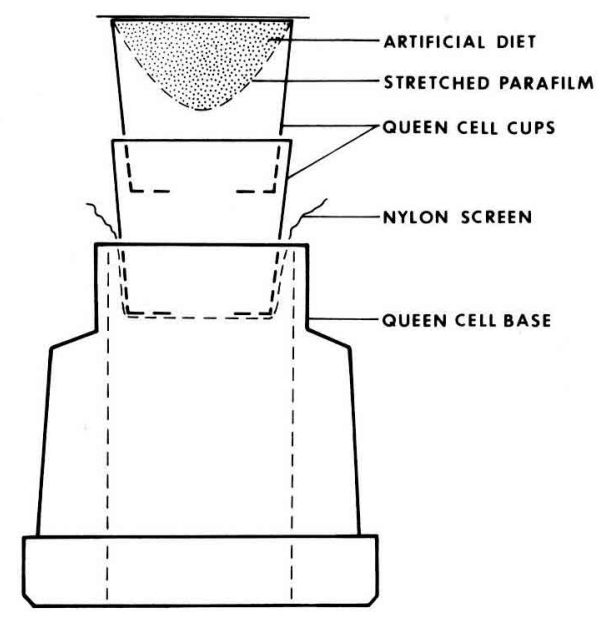

FlG. 1. - Modified honey bee queen-rearing cell to feed and culture Varroa jacobsoni.

\section{Test Procedure}

Larvac and pupae of Apis mellifera were each ground separately in a test tube and the resulting homogenate filtered and placed within a candidate membranc sac. Larval hemolymph was also obtained and tested in separate sacs. Methylene blue $\left(1 \mathrm{mg}: 100 \mathrm{ml}\right.$ distilled $\mathrm{H}_{2} \mathrm{O}$ ) was added to each sample as an indicator of feeding upon fluids. The presence of blue color in the gut or in the feces would prove uptake. One to three gravid, adult female $V$. jacobsoni were placed either directly on the sac or into a cell containing homogenate that had been fitted with a membrane.

Artificial diets (Bruce ${ }^{(5)}$; Hink unpublished) were also prepared, dyed with methylene blue, and placed in similar chambers with either adult female mites or immature stages for observation of feeding. Bruce's diet consisted basically of the following ingredients: Yeast hydrolysate, casein hydrolysate, Wesson's salt mixture, Vanderzant's vitamin mixture, cholesterol, sucrose gelatin, RNA solution, Tween 80 solution, chicken egg yolk and distilled water.

Mites were given the free choice of either artificial diet or a 6-11 day old pupa in the base of the queen cell. Mites were first placed on the pupa, then the nitex barrier was removed, allowing the mite to move frecly between the pupa and sac filled with artificial diet. Unless otherwise noted, all results are from tests conducted with Bruce's artificial dict.

(5) Bruce W.A., 1988. An artificial diet for a parasitic mitc, Pyemotes tritici (Acari : Pycmotidac). Exp. and Appl. Acarol. (Submitted August 5, 1987). 


\section{RESULTS AND DISCUSSION}

\section{Membrane Selection}

Membrane suitability tests showed that only Parafilm was penetrable. One possible explanation for the lack of penetration of the plastics by these mites is that, unlike $P$. tritici, $V$. jacobsoni does not possess cheliceral extensor musclers to move the chelicerae forward (Akımov and Yastrebtsov, 1983). Apparently, this species lacks the strength or was unable to brace itself against a hard surface to penetrate the plastics even though they are of the appropriate thickness $(10-15 \mu \mathrm{m})$. In addition, the chelicerae of $V$. jacot oni are larger and more blunt at the tip than the stylet-like structures of $P$. tritici, even though both are approximately the same effective length (approximately $15 \mu \mathrm{m}$ ). Also, the Parafilm sheets could be stretched consistently to approximately $10 \mu \mathrm{m}$ in thickness (verified by scanning electron microscopy) by pulling in both directions until tension stopped the pull.

\section{Test Chambers}

The modified micro ELISA blocks were somewhat unsatisfactory. This was because the cover sheet of Parafilm did not seal well to the diet-holding sheet when the micro ELISA was turned over to observe the results of feeding. However, of the 45 adult females set up in tests No. 1 and 2, all cells showed evidence (blue feces) within 3 days of feeding through a synthetic membrane. However, all but 6 females died after 3.5 days. In a third test, 44 out of 48 females drowned within 1 day because hemolymph leaked into the cells.

Results of feeding tests in which glass-tube chambers were used were also unsuccessful because of leaks along the uneven edges at the end of the tubes.

Modified queen cells were used for the remainder of the tests (beginning July 1) because few leaks occurred and observation was simplified. Also, from this point onward further tests employed artificial diets only, because it had been clearly demonstrated that adult females of $V$. jacobsoni would feed through a synthetic membrane on honey bee hemolymph dyed with methylene blue.

Results of the first test using artificial diet ( $V$. jacobsoni adult female mites removed from drone pupae) indicated feeding within $24 \mathrm{hr}$ in all cells (gut of female stained blue - blue feces in cell). In addition, four eggs, one each in 4 cells, had been laid ; three on the plastic side-walls of cell and one on the Parafilm sac. Two more eggs were laid during the next $24 \mathrm{hr}$ period, but after three days only 7 of 27 adult females remained alive and no eggs had 
hatched. However, three very significant events occurred during this test : (1) females of $V$. jacobsoni fed on an artificial diet, (2) females laid eggs on synthetic surfaces, and (3) both these results occurred under laboratory conditions.

This test, when repeated ( 5 cells, 3 mites/cell) with a slight modification in the artificial diet (chicken egg yolk removed), resulted in feeding in all cells and 7 eggs laid within the first $24 \mathrm{hr}$. After $48 \mathrm{hr}$ all females were alive and had fed ; four more eggs had been laid, three of which had hatched, and two protonymphs were alive. One egg laid during this second $24 \mathrm{hr}$ period contained methylene blue dye. This suggested that the egg was formed after feeding had begun and that perhaps some components (protein ?) of the diet were incorporated into the egg (Tewarson and JANY, 1982). After $72 \mathrm{hr} 12$ females were alive, three more eggs were laid (two blue), and four more eggs had hatched. After $120 \mathrm{hr} 6$ females were alive, one more blue egg was laid, and one protonymph had fed on the died as indicated by the presence of methylene blue in the gut.

This procedure was repeated three times and the results are combined and presented in Table 1 . About $75 \%$ of the eggs were laid within the first $24 \mathrm{hr}$, with the remainder on days two and three. Egg hatch began on day two and was completed by day four. Only a small percentage (28\%) of the eggs hatched. Adult female survival remained high until day four and dropped rapidly thereafter. The Hink artificial diet gave somewhat similar results in that all feeding stages fed on the diet but no adult females lived longer than two days and all stages that fed appeared slightly distended. In addition, while over half the eggs were blue (15 eggs laid - 9 blue), only one hatched. The preliminary results indicate the likelihood of developing an artificial diet that provides the nutritional requirements of $V$. jacobsoni is quite promising.

TABL. 1. - Varroa jacobsoni : Eggs laid and hatched after feeding on artificial diet containing methylene blue dye (1\% soln.).

\begin{tabular}{c|c|c|c|c|c}
\hline \hline \multirow{2}{*}{$\begin{array}{c}\text { Test } \\
\text { No. }\end{array}$} & \multirow{2}{*}{$\begin{array}{c}\text { No. } \\
\text { Females }\end{array}$} & \multicolumn{2}{|c|}{ Number of Eggs } & \multicolumn{2}{|c}{ Egg Hatch } \\
\cline { 3 - 6 } & & Total & Blue Color & Total & Blue Color \\
\hline 1 & 16 & 15 & 3 & 9 & 2 \\
2 & 30 & 25 & 6 & 8 & 2 \\
3 & 41 & 30 & 12 & 5 & 2 \\
\hline Total & 87 & 70 & 21 & 22 & 6 \\
\hline
\end{tabular}

It is unclear why apparently healthy eggs failed to hatch, why protonymphs did not molt or survive, and why adult females survived only a few 
days. In another study conducted concurrently, adult females of $V$. jacobsoni reared on honey bee larvae and pupae under similar conditions of temperature and humidity, in various environments, gave similar results for the immature stages. Adult females, however, survived several days longer when compared to the artificial diet (ChIEsA and MiLani, 1986). Both studies used the temperature and humidity regime described by SAKAI et al. (1979). It appears that some combination of temperature, humidity and air flow may also be critical.

Results of feeding tests with protonymphs and deutonymphs indicated that both instars could pierce the Parafilm sac and ingest the artificial diet. However, only 4 to 16 protonymphs and 2 of 8 deutonymphs actually fed, and only one of the deutonymphs molted. All appeared to be in the process of desiccating within $24 \mathrm{hr}$.

Results of the food choice selection were quite interesting. Of the 11 cells set up, 4 had to be discarded because the pupae were damaged. However, feeding on both pupae and artificial diet occurred in 4 of the remaining 7 cells as evidenced by the presence of both white and blue feces. This kind of behavior may indicate that few stimuli are required to initiate feeding, and that $V$. jacobsoni, because of its biology, indiscriminately probes whatever is within its environment, feeding on that which is acceptable. Normally this environment is the brood cell with only a larva or pupa being available as the food source.

During these studies, no attempt was made to use aseptic techniques either during preparation of the artificial diet or during testing, and as a consequence, mold frequently was a problem. It is not known what effect mold had on the results but clearly if an artificial diet is to be used in the mass-rearing of these mites, appropriate measures will need to be taken.

While not every objective was met, the following was clearly demonstrated :

(1) All feeding stages of $V$. jacobsoni were able to feed through a synthetic membrane on an artificial diet.

(2) Females oviposited within the environment of an artificial or plastic cell.

(3) Components of the artificial diet were observed to be incorporated into eggs.

(4) Eggs hatched to larvae, and larvae to protonymphs. Protonymphs did not complete development to the deutonymphal stage, and thus a complete life-cycle was not achieved.

Further studies to accomplish a complete life cycle and develop the massrearing techniques will be carried out at the Institute for Plant Protection, 
University of Udine, Udine, Italy and the Institute for Animal Health, Freiburg, FR Germany, respectively. Hopefully these results will stimulate the continued cooperation of the EEC with the various research organizations, including U.S. Department of Agriculture, to provide appropriate solutions to a very real threat to world agriculture.

Received for publication in July 1987. Accepted for publication in October 1987.

\title{
ACKNOWLEDGEMENTS
}

The authors thank Professor F. Frilu for his outstanding support and activity in helping to set up the multinational team which made this project possible. Also, the project could not have succeeded without the expertise of M. D'AGARo, beekeeping specialist, and the technical support of Dr. N. MLANI, both of the University of Udine, nor without the gracious provision by Dr. F. HINK of his artificial diet. We also thank Dr. R. Barbattini and M. G. Zugolo for their administrative assistance. Finally, we extend special thanks to Professor R. CAvalloro and the EC Committee on varroatosis for supporting the project.

\author{
RÉSUMÉ \\ ÉLEVAGE EN LABORATOIRE DE VARROA JACOBSONI OUDEMANS \\ (ACARI、VARROIDAE) SUR RÉGIMES ALIMENTAIRES NATUREL ET ARTIFICIEL
}

La possibilité d'élever Varroa jacobsoni Oudemans en laboratoire sur un régime artificiel a été suggéréc par Donald Griffiths à la suite de la $3^{*}$ Conférence Internationale sur la Protection des Denrées Entreposécs, qui s'est tenue à Manhattan (Kansas, USA) en 1983, où il a présentć unc communication sur la mise au point d'un régime artificiel et sur une méthode d'élevage en laboratoire de Pyemotes tritici (Lagrèze-Fossot and Montané), ectoparasite des insectes des denrées entreposées. Bien que $P$. tritici et $V$. jacobsoni percent tous deux le tégument de lcur hôte et se nourrissent de leur hémolymphe, il est difficile de comparer plus avant leur biologie. Il nous est néanmoins paru probable que $V$. jacobsoni soit ćgalement susceptible de se nourrir sur le même milicu artificiel que celui mis au point pour $P$. tritici et qu'il le fasse à travers la même membrane synthétique. La recherche a été menćc à l'Institut de

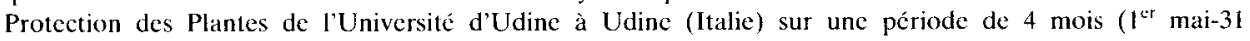
août 1986). Elle avait pour but de déterminer si :

1) la femelle adulte de $V$. jacobsoni pourrait explorer et percer une membrane synthétique, non vivante et se nourrir à travers ellc :

2) d'autres stades de développement pourraient égálement se nourrir à travers cette membrane :

3) $V$. jacobsoni pourrait se nourrir sur un régime artificiel ne provenant pas d'un insecte et pondre des aufs ;

4) $V$. jacobsoni pourrait accomplir son cycle de développement sur ce régime artificiel cl être ainsi ćlevé en laboratoire.

On a prélevé dans des colonies d'abeilles, Apis mellifica, tous les stades de développement de $V$. jacobsoni. Les cellules artificielles qui simulaient celles du rayon naturel ont étć préparécs à partir de cellules de reines en plastique modifiées en conséquence (Fig. 1) ou d'un bloc pour test micro-ELISA. 
On a choisi et testé un certain nombre de membranes synthétiques. Les tests initiaux pour déterminer la capacité de lacarien à se nourrir à travers la membrane ont utilisé un homogénat filtré d'hémolymphe larvaire et nymphale, coloré au bleu de méthylène. Par la suite un régime artificiel (Bruce, non publić) a ćté mis au point et testé dans les mêmes conditions.

La membranc synthétique choisic comme étant la micux adaptée est la membrane Parafilm ${ }^{(}+$; toutes les autres membranes testées ont donné des résultats négatifs. Parafilm, étirée pour avoir une épaisseur d'environ $10 \mu \mathrm{m}$, s'est montrée très efficace. Les tests initiaux qui utilisaicnt le bloc ELISA modifié et l'hémolymphe homogénéiséc et coloréc ont prouvé, par la présence de fèces colorés, la capacité de la femelle de $V$. jacobsoni à se nourrir à travers la membrane. Néanmoins on abandonna le bloc de test ELISA en raison de la perte de nourriture due à des problèmes de fuite.

Pour la suite des tests on a donc adapté des cellules de reine modifiées et le régime artificiel a remplacé l'hémolymphe homogénéisé. Avec cette technique, les femelles se sont nourries à travers la membrane, ont pondu des oufs à sa surface ou sur les côtés de la cellule, tout ceci dans des conditions de laboratoire $(35 \pm 1$ "C et $85 \%$ d'HR). La présence de bleu de méthylène à l'intérieur de certains aufs montre que l'ouf s'est formé après le début de l'alimentation et que certains composants du régime ont pu être incorporés à l'ouf. Environ $30 \%$ de ces oufs ont éclos au stade de protonymphe (Tabl, 1). Parmi celles-ci, on a pu en observer qui se nourrissaient mais aucune n'a subi la mue pour passer au stade de deutonymphe. De même, de nombreuses deutonymphes prélevées directement dans les cellules de couvain se sont nourries mais aucune n’a réussi à atteindre le stade adulte. II est à noter également que des femelles, auxquelles on donnait le libre choix de se nourrir naturellement sur une nymphe ou à travers une membrane synthétique, se sont réparties de façon aléatoire sur les deux, comme l'a prouvé la présence de fèces blancs et bleus dans la cellule de test.

\title{
ZUSAMMENFASSUNG
}

\author{
LABORAUFZUCHT VON VARROA JACOBSONI OUDEMANS \\ MIT NATÜRLICHER UND KÜNSTLICHER NAHRUNG (ACARI : VARROIDAE)
}

Die Möglichkeit, Varroa jacobsoni Oudemans im Labor auf künstlicher Diät aufzuziehen, wurde von Dr. Donald Griffiths auf der 3. Intern. Arbeitskonferenz über den Schutz von Lebensmittelvorräten in Manhattan. Kansas. USA, vorgetragen. Er präsentierte auf dieser Konferenz cinc Veröffentlichung über die Laboraufzucht von Pyemotes tritici (Lagrèze-Fossot und Montané), einem Ektoparasiten von Vorratsschädlingen, und über dessen Entwicklung bei künstlicher Diät. Obwohl beide Milben, $P$. tritici und $V$. jacobsoni das Integument ihres Wirtes durchbohren und sich von dessen Hämolymphe crnähren, sind weitere Vergleiche ihrer Biologic schwicrig. Trotzdem erschienen uns Spekulationen darüber annehmbar, daß sich $V$. jacobsoni von der gleichen künstlichen Diät wie $P$. tritici und ebenfalls durch eine synthetische Membran ernähren könnte.

Dic Untersuchungen wurden am Institut für Pflanzenschutz der Universität Udine, in Udine, Italien, während ciner Periode von 4 Monaten (1. Mai - 31. August 1986) durchgeführt. Als Zielvorstellung galt dic Bcantwortung folgender Fragen :

(1) Würden adulte $V$. jacobsoni-Weibchen dic tote, synthetische Membran untersuchen, durchbohren und Nahrung aufnehmen?

(2) Würden anderc Lebensstadien sich auch durch dic Membran crnähren?

(3) Würde sich $V$. jacobsoni von einer nicht von Insckten stammenden, künstlichen Diät ernähren und Eicr legen?

(4) Würde $V$. jacobsoni ihren Lebenszyklus mit der künstlichen Diät beenden und somit unter Laborbedingungen aufgezogen werden können?

Alle Lebensstadien von $V$. jacobsoni wurden aus Völkern der heimischen Honigbiene, Apis mellifera L. entnommen. Künstliche Zellen, die eine natürliche Wabe simulieren sollten, wurden aus entsprechend 
umgearbeiteten Königinnenzellen (Fig. 1) oder aus cinem Mikro-ELISA-Testblock hergcstellt. Eine Reihe von synthetischen Membranen wurde ausgewählt und getestet. Anfängliche Tests zur Bestimmung der Fähigkeit der Milbc, sich durch dic Membran hindurch zu ernähren, wurden mit einem gefilteren Homogenisat von larvaler und pupaler Hämolymphe, angefärbt mit Methylenblau, durchgeführt. Anschlicßend wurde cine künstliche Diät (BRuce, unveröffentlich) hergestellt und unter den gleichen Bedingungen getestet.

Die am besten gecignete synthetische Membran war Parafilm $\mathbb{( \mathbb { B }}^{+}$; alle anderen getesten Membranen ergaben negative Ergebnisse. Parafilm, der auf ungefähr $10 \mu \mathrm{m}$ Dicke ausgczogen wurde, ergab eine hohe Effektivität. Anfängliche Tests mit dem modifizierten ELISA-Block und angefärbtem HämolympheHomogenisat zeigten durch das Vorhandenscin angefärbten Kots die Fähigkeit von $V$. jacobsoniWeibchen sich durch eine künstliche Membran hindurch zu ernähren. Der ELISA-Testblock wurde jedoch später aufgegeben, da infolge von undichten Stellen Nahrung verloren ging.

Daher wurden die umgebauten Königinnenzellen für die restlichen Tests verwendet und anstelle von homogenisierter Hämolymphe die künstliche Diät. Mit dieser Technik konnten sich die Weibchen unter Laborbedingungen $\left(35 \pm 1^{\circ} \mathrm{C}\right.$ und $85 \% \mathrm{rF}$ ) durch die Membran hindurch ernähren und legten Eier auf der Membran oder an den Zellwänden ab. Der Nachweis von Methylenblau in cinigen Eiern wies darauf hin, daß die Eier gebildet wurden, nachdem die Fütterung begonnen hatte und wahrscheinlich einige Komponenten des künstlichen Futters in die Eier inkorporiert wurden. Etwa $30 \%$ dieser Eier entwickelten sich zum Protonymphenstadium (Tab. 1). Von diesen wurden einige bei der Nahrungsaufnahme beobachtet, aber keine entwickelte sich zur Deutonymphe. In gleicher Weise ernährten sich viele Deutonymphen, die aus Brutzellen entnommen wurden, von der künstlichen Diät, aber keine entwickkelte sich weiter zum adulten Stadium. Es sollte weiterhin vermerkt werden, daß Weibchen, denen eine freic Wahl zwischen der natürlichen Ernährung auf der Bienenpuppe oder der künstlichen durch die Membran hindurch geboten wurde, sich eher zufällig von beidem Futter crnährten, wie das Vorhandensein von weißem und blauem Kot in der Testzelle bewies.

\section{REFERENCES}

Akimov I.A. and Yastrebtsov A.V., 1983. - [The muscular system of the mite Varroa jacobsoni (Parasitiformes, Varroidae) : A parasite of the honey bee. I. Muscles of the gnathosoma]. Vestn. Zool. (2), 68-72 (in Russian).

Cavalloro R., 1983. - Varroa jacobsoni Oud. affecting honey bees : present status and needs. Proceedings. European Experts' Group Meeting on Varroatosis, R. Cavalloro ed., Wageningen, Netherlands.

Chiesa F. and Milani N., 1986. - Some preliminary observations on the behaviour of Varroa jacobsoni Oud. on its natural host under laboratory conditions. In "European Research on Varroatosis control "; Proceedings of a Meeting of the EC Experts' Group, Bad Homburg, 15-17 October 1986 (In press).

De Jong D., Morse R.A. and Eickwort G.C., 1982. - Mite pests of honey bees. Annu. Rev. Entomol., 27, 229-252.

Griffiths D.A., Gray J. and Pegazzano F., 1983. - Varroa - The acarologists' view. In : Proceedings European Experts' Group Meeting on Varroatosis, R. Cavalloro ed., Wageningen, Netherlands, $107 \mathrm{p}$.

Sakai T., Takeuchi K. and Hara A., 1979. - [Studies on the life history of a honeybee mite, Varroa jacobsoni Oudemans, in laboratory rearing]. Bull. Fac. Agric. Tamagawa Univ. (19), 95-103 (in Japanese).

Tewarson N.C. and JANY K., 1982. - Determination of protcolytic activity in Varroa jacobsoni and ectoparasitic hemophagous mite of honey bec (Apis sp.). Apidologie, 13 (4), 383-389. 